\title{
APLIKASI AKAD RAHN PADA PEGADAIAN SYARIAH
}

\author{
Luluk Wahyu Roficoh \\ Mahasiswi Pasca Sarjana Program Studi Hukum Ekonomi Syariah \\ Universitas Darussalam Gontor, \\ Email-lulukwahyu53@gmail.com
}

\section{Mohammad Ghozali}

Dosen Senior Fakultas Syariah dan Pasca Sarjana Program studi Hukum Ekonomi Syariah Universitas Darussalam Gontor, Email-mohammadghozali@unida.gontor.ac.id.

\begin{abstract}
Abstrak
Lembaga Keuangan Syariah di Indonesia menerapkan berbagai macam produk dan akad dalam menjalankan kegiatan usahanya, salah satu produknya adalah akad rahn yang ada di Pegadaian Syariah, adanya kebebasan untuk mendesain bentuk akad akan memberikan keberagaman produk, Namun demikian analisis figh dilakukan untuk menghindari hal-hal yang dilarang, mrngingat salah satu kaidah dalam ushul fiqh adalah pada dasarnya semua transaksi diperbolehkan kecuali ada dalil yang jelas melarangnya. Berdasarkan rukun akad rahn secara praktik mulai dari marhun, marhun bih, shighah, dan 'aqidaini sudah sesuai dengan dengan teori syariah, tetapi masih ada beberapa hal yang harus diperjelas untuk mendapatkan praktik yang benar secara teori syariah. Yaitu tentang pemanfaatan barang gadai yang belum dijelaskan secara rinci tentang pemanfaatan dari pihak rahin maupun dari pihak murtahin.
\end{abstract}

Keyword: Akad Rahn, Pegadaian Syariah 


\section{A. Pendahuluan}

Perkembangan sistem keuangan syariah ditandai dengan didirikannya berbagai lembaga keuangan syariah dan diterbitkannya berbagai instrumen keuangan berbasis syariah. Lembaga keuangan syariah secara esensial berbeda dengan lembaga keuangan konvensional, baik dalam tujuan, mekanisme, kekuasaan, ruang lingkup, serta tanggung jawabnya. Setiap institusi dalam lembaga keuangan syariah menjadi bagian integral dari sistem keuangan syariah. Lembaga keuangan syariah bertujuan membantu mencapai tujuan sosio-ekonomi masyarakat Islam. ${ }^{1}$

Pegadaian merupakan Salah satu solusi bagi masyarakat, ketika seseorang membutuhkan dana dalam kondisi yangmendesak dan cepat, sedangkan yang bersangkutan tidak memilikidana cash atau tabungan maka pendanaan pihak ketiga menjadialternative pemecahannya. Saat mengakses jasa perbankan bagibeberapa masyarakat akan menghadapi administrasi dan persyaratanyang rumit, sehingga sebagian orang akan datang pada rentenir, meskidengan bunga yang cukup tinggi. Bagi sebagian orang memilikiharta yang bisa dijadikan agunan, maka pegadaian pilihannya, sebabtransaksi gadai paling aman, legal dan terlembaga. ${ }^{2}$

Pembentukan Pegadaian Syariah selain karena tuntutan idealisme juga disebabkan keberhasilan terlembaganya bank, BMT, BPR dan asuransi syariah, pegadaian mendapat perhatian untuk dibentuk di bawah naungan suatu lembaga tersendiri. Atas dasar evaluasi dari perkembangan rahnsebagai produk perbankan syariah yang belum begitu baik, disebabkan oleh terbatasnya keberadaan komponen pendukung produk rahn seperti, sumber daya penafsir, alat untuk menafsir, dan gudang penyimpanan barang jaminan, bank tidak mampu memfasilitasi keberadaan rahn, tetapi rahn sangat dibutuhkan masyarakat. Sebab lain kurang baiknya perkembangan pegadaian syariah adalah masyarakat

${ }^{1}$ Andri Soemitra, Bank dan Lembaga Keuangan Syariah, (Jakarta: Kencana, 2016) Cet. VI, Hlm. 27.

${ }^{2}$ Rokhmat Subagiyo, Tinjauan Syariah Tentang Pegadaian Syariah (Rahn), Jurnal An-Nisbah, Vol. 1, No. 1, Oktober 2014, Hlm. 162. 
belum banyak mengenal rahnsebagai lembaga keuangan mandiri. Melihat realitas tersebut, keberadaan pegadaian syariah tidak bisa ditunda lagi sehingga pada tahun 2003 didirikan Pegadaian Syariah. ${ }^{3}$ Dengan semakin berkembangnya pegadaian syariah hingga kini produk yang ditawarkan yaitu, arrum haji, multi pembayaran online, konsinyasi emas, tabungan emas, mulia, arrum BPKB, amanah, rahn, dan gadai syariah. ${ }^{4}$

\section{B. Akad Rahn}

Dalam Fiqh konsep gadai disebut dengan rahn. Kata al-Rahnberasal dari bahasa Arab, secara bahasa rahn adalah al-tsubut wa al-dawam yang berarti tetap dan kekal. ${ }^{5}$ Menurut Wahbah Zuhaily rahn adalah menahan salah satu harta milik peminjam sebagai jaminan atas pinjaman yang diterimanya. Barang yang ditahan tersebut memiliki nilai ekonomis. ${ }^{6}$ Menurut Sayyid Sabiq, rahn adalah menjadikan barang berharga menurut pandangan syara' sebagai jaminan utang. ${ }^{7}$ Menurut Al-Qurthubi rahn adalah barang yang ditahan oleh pihak memberi utang sebagai bentuk jaminan dari orang yang berutang, sampai pihak yang berutang melunasi utang tersebut. ${ }^{8}$ Menurut Ibnu Qudamah rahnadalah harta yang dijadikan jaminan dalam utang, agar pemberi utang dapat menjual barang tersebut apabila pihak yang berutang tidak mampu membayar utangnya. ${ }^{9}$ Pasal 20 ayat $14 \mathrm{KHES}^{10}$ memberikan definisi Rahn atau gadai adalah penguasaan barang milik peminjam oleh pemberi pinjam sebagai jaminan.

Berdasarkan pendapat yang dipaparkan ulama rahnyang dimaksudkan adalah menjadikan barang berharga sebagai jaminan utang sehingga orang yang bersangkutan boleh mengambil utang. ${ }^{11}$ Dengan

\footnotetext{
${ }^{3}$ Heri Sudarsono, Bank dan Lembaga Keuangan Syariah Deskripsi dan Ilustrasi, (Yogyakarta: Penerbit Ekonisia, 2015), Cet. 3, Hlm. 173.

${ }^{4}$ Pegadaiansyariah.co.id/rahn, diakses Rabu, 10 April 2018.

${ }^{5}$ Abu Zakariya Yahya ibn Syarif Al-Nawawi, Mughni al-Muhtaj, (Mesir: Musthafa al-Babi al-Halabi, 1957), Juz II, Hlm. 121.

${ }^{6}$ Wahbah Zuhaili, Al-fiqh al-Islami wa Adillatuhu, (Damaskus: Daar al Fikr, 1989), cet. III, Hlm. 180.

${ }^{7}$ Sayyid Sabiq, Fiqh Sunnah, (Beirut: Daar kitab al-Arabi, 1971), jilid III, Hlm. 153.

${ }^{8}$ Abu Amr Yusuf Ibn Abdullah Ibn Abdul Al-Bar Ibn Ashim Al-Numari Al-Qurthubi, Al-Kafi Fi Fiqh Ahlu Madinah AlMaliki, (Saudi Arabia: Maktabah Al-Riyadh Al-Haditsah, 1980), Juz. II, Hlm. 812.

9 Abu Muhammad Abdullah Ibn Ahmad Ibn Muhammad Ibn Qudamah Al-Maqdisi, Al-Mughni wa Yalihi Al-Syarh AlKabir, (Kairo: Dar Al-Hadist, 2004) Juz. VI, Hlm. 23.

${ }^{10}$ KHES adalah Kompilasi Hukum Ekonomi Syariah yang disusun oleh Mahkamah Agung Republik Indonesia bersama tim penyusun.

${ }^{11}$ Panji Adam, Fatwa-Fatwa Ekonomi Syariah: Konsep, Metodologi, dan Implementasinya pada Lembaga Keuangan Syariah, (Jakarta: Amzah, 2018), Hlm. 278. 
begitu jaminan tersebut berkaitan erat dengan utang piutang. Sebenarnya pemberian utang merupakan suatu tindakan kebajikan untuk menolong orang lain. Namun, untuk ketenangan hati pemberi utang memberikan suatu jaminan, bahwa utang itu akan dibayar oleh yang berutang. Untuk maksud itu pemilik uang boleh meminta jaminan dalam bentuk barang berharga. $^{12}$

Dasar hukum Rahn terdapat pada al-Qur'anSurat Al-Baqarah ayat 283 yang artinya Jika kamu dalam perjalanan dan bermuamalah secara tunai sedang kamu tidak mendapatkan seorang penulis, maka hendaklah ada barang tanggungan yang dipegang oleh yang berpiutang. Dinyatakan dalam ayat ini bahwa apabila seseorang bermuamalat secara tidak tunai maka hendaknya ada barang jaminan milik pihak berutang dipegang oleh pihak berpiutang. Dasar hukum as-Sunnah tentang rahn ini terdapat pada hadist yang diriwayatkan oleh Anas bin Malik yang menyatakan bahwa Rasulullah menggadaikan baju besinya pada seorang Yahudi di Madinah dan beliau mengambil jagung untuk keluarganya. ${ }^{13}$

Payung hukum gadai syariah dalam hal pemenuhan prinsip-pripsip syariah berpegang pada Fatwa DSN MUI No. 25/DSN-MUI/III/2002 tentang rahn, Fatwa DSN MUI No. 26/DSN-MUI/III/2002 tentang gadai emas, DSN MUI juga menerbitkan Fatwa DSN MUI No. 68/DSNMUI/III/2008 tentang Rahn Tasjily. Dengan adanya fatwa yang dikeluarkan DSN MUI menjadi rujukan dan legalitas yang berlaku umum bagi lembaga keuangan syariah di Indonesia. Dalam aspek kelembagaan menginduk kepada Peraturan Pemerintah Nomor 103 Tahun 2000.

Mayoritas Ulama berpendapat bahwa Rukun rahn adalahadanya jaminan berupa barang atau harta (marhun),adanya utang (marhun bih), adanya Shighah kesepakatan antara rahindan murtahindalam melakukan transaksi rahn, adanya 'aqidainidua pihak yang melakukan transaksi yaitu pihak yang menyerahkan barang (rahin)dan pihak penerima barang (murtahin). Hanafiyyah berpendapat bahwa rukun rahnhanya satu, yaitu 
shighah, karena shighah adalah hakikat dari transaksi, dan selain shighah hanya termasuk syarat rahn, bukan rukunrahn. ${ }^{14}$ Menurut Sayyid Sabiq hal yang disyaratkan dalam rahnadalah berakal, baligh, barang yang digadaikan ada pada saat akad dan barang tersebut diterima oleh murtahinatau wakilnya. ${ }^{15}$

Ulama sepakat bahwa serah terima(qabdh) merupakan syarat utama dalam akad rahn, dan akad dikatakan sah apabila, serah terima dilakukan berdasarkan izin dari rahin, jika tidak mendapatkan izin, maka akad tidak sah. Ketika serah terima dilakukan maka semua syarat 'aqidaini, marhun bih danmarhun harus sudah dipenuhi, karena serah terima bersifat permanen, artinya marhuntetap dalam genggaman murtahindan tidak bisa dikembalikan kepada rahin, rahinboleh meminta marhununtuk dimanfaatkan dengan izinmurtahindengan catatan, marhuntidak rusak nilainya ketika dimanfaatkan. Ketika akad rahn telah disepakati antara rahin dan murtahin dan telah terjadi serah terima marhun,maka marhun akan terus terikat dengan utang yang ada dan tetap ditahan selama utang yang ada belum dibayar, danterdapat konsekuensi hukum yang melingkupinya. $^{16}$

\section{Pemanfaatan barang gadai}

Dalam pemanfaatan marhun oleh rahin ulama berbeda pendapat, menurut Hanafiyahrahintidak memiliki hak memanfaatkan marhun tanpa seizin murtahin, dan juga sebaliknya. Dengan alasan, murtahin memiliki hak atas marhun sehingga rahin tidak dapat meminta marhun tanpa seizin murtahin, dan jika ada kerusakan ketika pemanfaatan, maka rahinbertanggung jawab mengganti senilai kerusakan. Begitu juga Hanabalah, rahin tidak bisa memanfaatkan marhun tanpa seizin murtahin. Hal ini berlandaskan pada prinsip bahsa segala manfaat dan nilai yang dihasilkan marhun, akan dikembalikan kepada rahin.

\footnotetext{
14 Abdullah bin Muhammad Ath-Thayyar, Abdullah bin Muhammad Al-Muthlaq, Muhammad bin Ibrahim Al-Musa, Ensiklopedia Fiqih Muamalah dalam pandangan 4 Madzhab, (Yogyakarta: Maktabah Al-Hanif, 2017), Cet. IV, Terj. Miftahul Khairi, Hlm. 175

${ }^{15}$ Syaikh Sulaiman bin Ahmad bin Yahya Al-Faifi, Ringkasan Fiqih Sunnah (Kitab Fiqih Sunnah Syaikh Sayyid Sabiq), (Depok: Senja Media Utama, 2017), Cet. I, Terj. Achmad Zaeni Dachlan, Hlm. 624.

${ }^{16}$ Dimyauddin Djuwaini, Pengantar Fiqh Muamalat, (Yogyakarta: Pustaka Pelajar, 2015), Cet. 3, Hlm. 264.
} 
Ulama Malikiyah mengatakan, bahwa rahin tidak memiliki hak untuk memanfaatkan marhun, mereka menetapkan bahwa izin yang diberikan murtahin kepada rahin untuk memanfaatkan marhun dapat membatalkan akad rahn. Berbeda dengan Syafi'iyah, rahin memiliki hak untuk memanfaatkan marhun, selama tidak mengurangi nilai ekonomis yang melekat di dalamnya, seperti mengendarai kendaraan, menempati rumah, dengan alasan manfaat dan produktivitas marhun tetap menjadi milik rahin. Jika pemanfaatan tersebut mengurangi nilai marhun, maka tidak diperbolehkan kecuali seizin murtahin.

Dalam pemanfaatan marhun oleh murtahin menurut Hanafiyah, murtahin tidak memiliki hak untuk memenfaatkan marhuntanpa seizin rahin, karena ia hanya memiliki hak untuk menahan, bukan memanfaatkan. Menurut sebagian ulama Hanafiyah hal ini tidak diperbolehkan karena murtahin mendapat nilai manfaat lebih hal ini identik dengan riba. Begitu juga dengan Malikiyah, jika hutang ini berupa pinjaman (qardh), maka memanfaatkan marhun identik dengan riba. Syafi'iyah menambahkan murtahin tidak memiliki hak pemanfaatanmarhun.

Akad rahnadalah akad yang dimaksudkan sebagai jaminan uang, bukan untuk mendapatkan keuntungan dan hasil darinya. Jika hal itu dilakukan, murtahin tidak boleh memanfaatkan barang yang digadaikan, karena hal itu sama seperti pinjaman yang mendatangkan keuntungan, dan setiap pinjaman yang mendatangkan keuntungan adalah riba. Hal ini berlaku untuk barang gadai selain hewan yang bisa ditunggangi atau hewan perah yang bisa diperah susunya. ${ }^{17}$

Jika rahin melakukan transaksi jual beli atas marhun tanpa seizin murtahin, maka jual beli tersebut sama seperti hukumnya mauquf, ${ }^{18}$ karena ada hak murtahin dalam marhun, jika murtahin memberi izin maka jual beli tersebut diperbolehkan, begitu juga murtahin tidak memiliki hak

\footnotetext{
${ }^{17}$ Syaikh Sulaiman bin Ahmad bin Yahya Al-Faifi, Ringkasan Fiqih Sunnah (Kitab Fiqih Sunnah Syaikh Sayyid Sabiq), Hlm. 625.

${ }^{18}$ Akad mauquf adalah akad yang tergantung suatu hak pada orang lain yaitu berasal dari orang yang tidak punya kekuasaan syar' $i$ untuk melakukan akad, seperti anak kecil mampu melakukan transaksi (mumayiz) dan hanya akan berimplikasi yuridis jika diberi izin oleh walinya, jika tanpa wali, akad tersebut akan batal. Akad mauquf termasuk akad yang bathil (batal demi hukum) yang tidak berimplikasi apapun, maka apapun yang diadakan dianggap tidak pernah terjadi.
} 
untuk melakukan transaksi atas marhun tanpa seizin rahin. Posisi murtahin atas marhun adalah yad amanah, ketika murtahinmenahan marhun, maka murtahinberkewajiban untuk menjaganya sebagaimana ia menjaga harta kekayaan pribadinya, jika marhun diserahkan kepada orang lain dan terjadi kerusakan, maka ia berkewajiban untuk menggantinya. Namun, nilai kerusakan itu tidak bisa mengurangi nominal hutang yang ada.

\section{Pegadaian Syariah}

Dinas pegadaian yang merupakan kelanjutan dari pemerintahan Hindia Belanda merubah status pegadaian menjadi Perusahaan Negara (PN) Pegadaian berdasarkan Undang-Undang No. 19 Prp 1960 jo dan Peraturan pemerintah RI No. 178 Tahun 1960 tanggal 3 Mei 1960 tentang Pendirian Perusahaan Pegadaian (PN Pegadaian). Kemudian Peraturan Pemerintah RI No. 7 tahun 1969 Tanggal 11 Maret 1969 tentang perubahan kedudukan PN Pegadaian menjadi Jawatan Pegadaian jo UU No. 9 tahun 1969 tanggal 1 Agustus 1969 dan penjelasannya mengenai bentuk bentuk usaha negara dalam Perusahaan Jawatan (Perjan), ${ }^{19}$ Perusahaan Umum (Perum), ${ }^{20}$ dan Perusahaan Perseroan (Persero). ${ }^{21}$ Untuk meningkatkan efektivitas dan produktivitasa, bentuk Perjan Pegadaian tersebut kemudian dialihkan menjadi Perum Pegadaian berdasarkan Peraturan Pemerintah No. 10 Tahun 1990 tanggal 10 April 1990. Badan hukum Pegadaian dirubah lagi menjadi Perusahaan Perseroan (Persero) berdasarkan Peraturan Pemerintah RI No. 51 Tahun 2011 tanggal 13 Desember 2011. pada waktu pegadaian berbentuk Perusahaan Jawatan misi sosial dari pegadaian merupakan satu-satunya acuan yang digunakan oleh managemen dalam mengelola pegadaian. ${ }^{22}$

\footnotetext{
${ }^{19}$ Perjan (Perusahaan Jawatan) adalah bentuk badan usaha milik negara yang seluruh modalnya dimiliki oleh pemerintah. Perjan ini berorientasi pelayanan pada masyarakat, sehingga selalu merugi. Sekarang sudah tidak ada perusahaan BUMN yang menggunakan model perjan karena besarnya biaya untuk pemeliharaan.

${ }^{20}$ Perum (Perusahaan Umum) adalah perjan yang sudah diubah. Tujuannya tidak lagi berorientasi pelayanan tetapi profit oriented. Perum dikelola oleh negara dengan status pegawainya sebagai pegawai negeri. Namun perusahaan masih merugi walaupun status perjan diubah menjadi perum.

${ }^{21}$ Persero adalah salah satu badan usaha yang dikelola oleh negara atau daerah. Berbeda dengan perum atau perjan, tujuan didirikannya Persero yang pertama adalah mencari keuntungan dan yang kedua adalah memberi pelayanan kepada umum. Modal pendirian berasal dari kekayaan negara yang dipisahkan berupa saham-saham. Persero dipimpin oleh direksi, dan status pegawainya adalah pegawai swasta.

${ }^{22}$ Heri Sudarsono, Bank dan Lembaga Keuangan Syariah Deskripsi dan Ilustrasi, Hlm. 173.
} 
Pegadaian merupakan lembaga pembiayaan atau perkreditan dengan sistem gadai,PT Pegadaian merupakan salah satu perusahaan dibawah naungan Kementrian BUMN, ${ }^{23}$ Tugas pokok PT Pegadaian adalah menjembatani kebutuhan dana masyarakat dengan pemberian uang pinjaman berdasarkan hukum gadai. Bersamaan dengan berkembangnya produk syariah di Indonesia,Pada tahun 2003 sektor pegadaian juga mendirikan pegadaian syariah dengan membentuk Unit Layanan Gadai Syariah (ULGS), yang dalam pelaksanaannya berpegang kepada prinsip syariah. Hingga kini Pegadaian Syariah masih menginduk pada PT Pegadaiandan direncanakan spin off ${ }^{24}$ pada tahun $2019 .{ }^{25}$

Konsep operasi pegadaian syariah mengacu pada sistem administrasi modern dengan asas rasionalitas, efesiensi, dan efektivitas dengan nilai Islam. Fungsi operasi pegadaian syariah dijalankan di kantorkantor cabang pegadaian syariah atau ULGS sebagai satu unit organisasi di bawah binaan Divisi Usaha Lain PT Pegadaian, dan merupakan unit bisnis mandiri yang secara struktural terpisah dari usaha gadai konvensional. Unit Usaha Layanan Syariah cabang Dewi Sartika di Jakarta adalah pegadaian syariah pertama, berdiri pada Januari tahun 2003. Dan selanjutnya pendirian ULGS di Surabaya, Makasar, Semarang, Surakarta dan Yogyakarta hingga bulan September 2003, di tahun yang sama pula, 4 kantor cabang pegadaian di Aceh di konversi menjadi kantor Pegadaian Syariah. ${ }^{26}$

\section{E. Aplikasi akad Rahn pada Pegadaian Syariah}

Mekanisme operasional Pegadaian Syariah melalui akad rahnadalah dengan masyarakat menyerahkan barang bergerak dan kemudian pegadaian menyimpan dan merawat barang tersebut di tempat yang telah

\footnotetext{
${ }^{23}$ BUMN adalah kepanjangan dari Badan Usaha Milik Negara yang mempunyai tugas pokok menyelenggarakan urusan pemerintahan di bidang Badan Usaha Milik Negara, yang selanjutnya dalam Peraturan Menteri ini disebut BUMN, untuk membantu Presiden dalam menyelenggarakan pemerintahan negara. Pembinaan Badan Usaha Milik Negara tersebut termasuk pembinaan entitas yang dikendalikan oleh BUMN baik secara langsung maupun tidak langsung.

${ }^{24}$ Spin Offadalah proses pemisahan kepemilikan suatu usaha yang biasanya dilakukan karena beberapa faktor. Salah satunya adalah bisnis yang makin prospektif ke depannya. Menurut UU No. 21 Tahun 2008 tentang Perbankan Syariah, bank yang akan menjalankan proses spin off adalah ketika telah mencapai 50 persen dari total aset bank induknya atau telah beroperasi selama 15 tahun sejak berlakunya UU.

${ }^{25}$ Andri Soemitra, Bank dan Lembaga Keuangan Syariah, Hlm. 400-401.

${ }^{26}$ Arif Efendi, Gadai Syariah dalam Prespektif Ekonomi Islam Studi tentang Layanan Syariah Rahn pada PT Pegadaian Persero, Jurnal Wahana Akademika, Vol. 15 No. 01, April 2013, Hlm. 38. 
disediakan oleh pegadaian. Akibat dari proses penyimpanan adalah timbulnya biaya-biaya yang meliputi nilai dari tempat penyimpanan, biaya perawatan dan keseluruhan proses kegiatan. Atas dasar ini dibenarkan bagi pegadaian mengenakan biaya sewa bagi nasabah sesuai jumlah yang disepakati oleh kedua belah pihak. Pegadaian Syariah akan mendapatkan keuntungan hanya dari beasewa tempat yang diambil bukan tambahan berupa bunga atau sewa modal yang diperhitungkan dari uang pinjaman. ${ }^{27}$ Dalam hal ini, Akad rahnyang dimaksudkan adalah produk pembiayaan rahnyang ada di Pegadaian Syariah.

Transaksi gadai menurut syariah harus memenuhi rukun dan syaratnya. Pada dasarnya pegadaian syariah berjalan atas dua akad transaksi, yaitu ${ }^{28}$ akad $R a h n^{29}$ dan akad ljarah. ${ }^{30}$ Kedua akad akan ditandatangani sekaligus pada saat nasabah (rahn) menyerahkan hartanya. Nasabah (rahn) mengembalikan utang itu sesuai dengan jumlah utangnya. Akad ijarah, nasabah dibebani membayar ujrah (bea penyimpanan) kepada pegadaian.

Jenis barang yang dapat diterima sebagai barang jaminan pada prinsipnya adalah barang bergerak, antara lain: ${ }^{31}$

1. Barang-barang perhiasan, yaitu semua perhiasan yang dibuat dari emas, perhiasan perak, platina, baik yang berhiaskan intan, mutiara.

2. Barang-barang elektronik: laptop, TV, kulkas, radio, tape recorder, $\mathrm{vcd} / \mathrm{d} v \mathrm{~d}$, radio kaset.

3. Kendaraan: Sepeda, Sepeda Motor, Mobil.

4. Barang-barang rumah tangga

5. Mesin: mesin jahit, mesin motor kapal

\footnotetext{
${ }^{27}$ Andri Soemitra, Bank dan Lembaga Keuangan Syariah, Hlm. 404.

${ }^{28}$ Ibid, Hlm. 403-404.

${ }^{29}$ Akad Rahn, Rahn yang dimaksud adalah menahan harta milik si peminjam sebagai jaminan atas pinjaman yang diterimanya. Dengan akad ini pegadaian menahan barang bergerak sebagai jaminan atas utang nasabah.

${ }^{30}$ Akad Ijarah. Yaitu, akad pemindahan hak guna atas barang atau jasa melalui pembayaran upah sewa, tanpa diikuti dengan pemindahan kepemilikan atas barangnya sendiri. Melalui akad ini dimungkinkan bagi pegadaian untuk menarik sewa atas penyimpanan barang bergerak milik nasabah yang telah melakukan akad.

${ }^{31}$ Kasmir, Bank dan Lembaga Keuangan Lainnya, (Jakarta: PT Rajagrafindo, 2008) Hlm. 266
} 
6. Barang-barang lain yang dianggap bernilai seperti surat-surat berharga baik dalam bentuk saham, obligasi, maupun surat-surat berharga lainnya.

Pembiayaan rahndi pegadaian syariah adalah solusi tepat kebutuhan dana cepat yang sesuai syariah. Prosesnya cepat hanya dalam waktu 15 menit dana cair dan aman penyimpanannya. Jaminan berupa barang perhiasan, elektronik ataukendaraan bermotor dan barang bergerak lainnya. Keunggulan produk ini adalah: ${ }^{32}$

1. Layanan rahnada di outlet pegadaian syariah seluruh Indonesia,

2. Prosedur pengajuannya sangat mudah,

3. Proses peminjaman sangat cepat hanya 15 menit,

4. Pinjaman (Marhun Bih) mulai dari 50 ribu rupiah sampai 500 juta rupiah atau lebih,

5. Jangka waktu pinjaman maksimal 4 bulan atau 120 hari dan dapat diperpanjang berkali-kali dengan cara membayar ijarah saja atau mengangsur sebagian uang pinjaman,

6. Pelunasan dapat dilakukan sewaktu-waktu dengan perhitungan ijarah selama masa pinjaman,

7. Proses pinjaman tanpa perlu membuka rekening,

8. Nasabah menerima pinjaman dalam bentuk tunai atau di transfer ke rekening,

9. Barang jaminan tersimpan aman di pegadaian.

Model bisnis gadai syariah yang mudah dan cepat di Pegadaian Syariah adalah sebagai berikut: ${ }^{33}$

1. Nasabah datang membawa (Marhun) agunan,

2. Marhun ditaksir oleh Penaksir dari Pegadaian Syariah,

3. Marhun bih diterima oleh nasabah tunai atau ditransfer.

Dengan persyaratan, sebagai berikut: ${ }^{34}$

1. Fotokopi KTP atau kartu indentitas resmi lainnya,

2. Memiliki barang jaminan,

${ }^{32}$ Pegadaiansyariah.co.id/rahn, diakses Rabu, 10 April 2018.

${ }^{33} \mathrm{Ibid}$, Pegadaiansyariah.co.id/rahn, diakses Rabu, 10 April 2018.

${ }^{34}$ Ibid, Pegadaiansyariah.co.id/rahn, diakses Rabu, 10 April 2018. 
3. Untuk kendaraan bermotor membawa BPKB dan STNK asli.

4. Nasabah menandatangani Surat Bukti Rahn (SBR).

Ketentuan akad rahndi Pegadaian Syariah:

1. Jangka waktu akad maksimum 120 hari pinjaman (agar diunasi) atau diperpanjang utang rahn, meninggalkan marhun bih dan sampai dengan tanggal jatuh tempo.

2. Bila transaksi pelunasan dan perpanjangan akad dilakukan oleh rahindi cabang atau unit Pegadaian Syariah online atau tempat yang ditunjuk oleh murtahin, maka rahintelah menyetujui nota transaksi (struk) sebagai addendum ${ }^{35}$ perjanjian surat bukti rahnini.

3. Dalam hal menjadi perpanjangan akad sampai tanggal jatuh tempo, tanggal lelang dan bertahannya marhun bih tercantum dalam nota transaksi (struk).

4. Permintaan penundaan utang dapat dilayani sebelum jatuh tempo dengan mengisi formulir yang telah disediakan. Penundaan utang dikenakan biaya sesuai ketentuan yang berlaku di murtahin.

5. Surat Bukti Rahn (SBR) dan nota transaksi (struk) harus disimpan dengan baik, jika hilang harus melapor ke cabang atau unit pegadaian syariah penerbit Surat Bukti Rahn.

6. Pengembalian marhun bih harus menyerahkan SBR dan menunjukkan kartu pengenal (KTP/SIM).

7. Rahin wajib menaati ketentuan akad yang ada di Surat Bukti Rahn beserta addendumnya.

Pegadaian sebagai lembaga keuangan tidak diperkenankan menghimpun dana secara langsung dari masyarakat dalam bentuk simpanan. Untuk memenuhi kebutuhan dananya, PT Pegadaian memiliki sumber-sumber dana sebagai berikut: Modal sendiri, Penyertaan modal pemerintah, Pinjaman jangka pendek dari perbankan, Pinjaman jangka

\footnotetext{
${ }^{35}$ Addendum adalah jilid tambahan, istilah addendum digunakan saat ada tambahan atau lampiran pada perjanjian pokok namun merupakan satu kesatuan dengan perjanjian pokoknya. Meskipun jangka waktu perjanjian tersebut belum berakhir, para pihak dapat menambahkan addendum sepanjang disepakati oleh kedua belah pihak. 
panjang yang berasal dari kredit lunak Bank Indonesia, Dari masyarakat melalui penerbitan obligasi. ${ }^{36}$

Sifat usaha pegadaian pada prinsipnya menyediakan pelayanan bagi kemanfaatan masyarakat umum. Oleh karena itu, PT Pegadaian bertujuan sebagai berikut: ${ }^{37}$

1. Turut melaksanakan dan menunjang pelaksanaan kebijakan dan program pemerintah di bidang ekonomi dan pembangunan nasional pada umumnya melalui penyaluran uang pembiayaan atau pinjaman atas dasar hukum gadai.

2. Pencegahan praktik ijon, pegadaian gelap, dan pinjaman tidak wajar lainnya.

3. Pemanfaatan gadai bebas bunga pada gadai syariah memiliki efek jaring pengaman sosial karena masyarakat yang butuh dana mendesak tidak lagi dijerat pinjaman atau pembiayaan berbasis bunga.

Adapun manfaat pegadaian antara lain: ${ }^{38}$

1. Bagi Nasabah: tersedianya dana dengan prosedur yang relatif lebih sederhana dan dalam waktu yang lebih cepat dibandingkan dengan pembiayaan atau kredit perbankan. Di samping itu, nasabah juga mendapat manfaat penaksiran nilai suatu barang bergerak secara profesional. Mendapat fasilitas penitipan barang bergerak yang aman dan dapat dipercaya.

2. Bagi perusahaan pegadaian:

a. Penghasilan yang bersumber dari sewa modal yang dibayarkan oleh peminjam dana.

b. Penghasilan yang bersumber dari ongkos yang dibayarkan oleh nasabah memperoleh jasa tertentu. Bagi bank syariah yang mengeluarkan produk gadai syariah mendapatkan keuntungan

\footnotetext{
${ }^{36}$ Dahlan Siamat, Manajemen Lembaga Keuangan, (Jakarta: Lembaga Penerbit Fakultas Ekonomi Universitas Indonesia, 2004), Edisi Keempat, Hlm. 504-505.

${ }^{37}$ Andri Soemitra, Bank dan Lembaga Keuangan Syariah, Hlm. 394.

${ }^{38}$ Panji Adam, Fatwa-Fatwa Ekonomi Syariah: Konsep, Metodologi, dan Implementasinya pada Lembaga Keuangan Syariah, Hlm. 286-287. 
dari pembebanan biaya administrasi dan biaya sewa tempat penyimpanan emas.

c. Pelaksanaan misi PT Pegadaian sebagai BUMN yang bergerak di bidang pembiayaan berupa pemberian bantuan kepada masyarakat yang memerlukan dana dengan prosedur relatif sederhana.

Aspek syariah tidak hanya menyentuh bagian operasionalnya saja, pembiayaan kegiatan dan pendanaan bagi nasabah, harus diperoleh dari sumber yang benar-benar terbebas dari unsur riba. Seluruh kegiatan pegadaian syariah termasuk dana yang kemudian disalurkan kepada nasabah, murni berasal dari modal sendiri ditambah dana pihak ketiga dari sumber yang dapat dipertanggungjawabkan. Pegadaian telah melakukan kerja sama dengan Bank Muamalat sebagai fundemya, kedepan bank syariah juga akan melakukan kerja sama dengan lembaga keuangan syariah lain untuk memback-up modal kerja. ${ }^{39}$

Apabila nasabah belum bisa melunasi utangnya dan kewajibannya, maka gadai itu bisa diperpanjang. Nasabah cukup membayar biaya simpan dan biaya administrasi. Sedangkan jika rahintidak mampu melunasi utang dan kewajibannya, dan juga tidak memperpanjang gadainya, maka setelah tenggat waktu tertentu atau setelah murtahinmemberi peringatan, maka kreditur bisa mengeksekusi harta yang digadaikan dan selanjutnya akan dilakukan pelelangan.

Praktik rahn pada prinsipnya hampir sama dengan praktik gadai secara konvensional, ada barang yang digunakan sebagai jaminan untuk kreditur (murtahin) atas pinjaman yang diberikan kepada debitur (rahin) pemeliharaan dan penyimpanan atas marhunpada hakikatnya adalah kewajiban rahin. Besarnya biaya pemeliharaan dan penyimpanan atas marhunditentukan dengan akad ijarah, adanya akad ijarah inilah yang membedakan antara gadai konvensional dengan rahn. ${ }^{40}$

\footnotetext{
${ }^{39}$ Andri Soemitra, Bank dan Lembaga Keuangan Syariah, Hlm. 424.

${ }^{40}$ Naida Nur Alfisyahri dan Dodik Siswantoro, Praktik dan Karakteristik Gadai Syariah di Indonesia, Jurnal Share, Vol. 1, No. 2, Juli-Desember 2012, Hlm. 121. 


\section{F. AnalisisAkad Rahn di Pegadaian Syariah}

Akad secara syariat dibagi menjadi dua, akad shahih dan akad ghairu shahih, ${ }^{41}$ akad shahih adalah akad yang sempurna rukun-rukun dan syarat-syarat menurut syariah dan berkalu akibat ditimbulkan oleh akad dan mengikat secara pasti oleh pihak-pihak yang berakad. ${ }^{42}$ Sebuah akad akan dikatakan shahih, apabila sudah memenuhi rukun dan syaratnya, begitu pula dengan akad rahn atau produk pembiayaan rahndi Pegadaian Syariah.

Apabila dilihat dari rukun akad rahn yang pertama adalah adanya jaminan (marhun). Secara teori barang yang bisa dijadikan Syarat yang terkait dengan barang jaminan (marhun) adalah yang mempunyai nilai ekonomis, harus bisa ditransaksikan dan bisa diserahterimakan ketika akad. Harus berupa harta yang berharga dan dapat dimanfaatkan atau mal al mutaqaqqim, apabila manfaat saja, barangtidak bisa dijadikan marhunkarena ia tidak bisa diserahterimakan ketika akad, selain itu manfaat tidak bisa diketahui nilainya secara jelas. Marhunmerupakan milik mutlak rahindan tidak terdapat hak orang lain dalam marhun. ${ }^{43}$

Secara praktik barang yang diterima untuk dijadikan jaminan (marhun) di Pegadaian Syariah adalah barang bergerak yang meliputi perhiasan, elektronik, kendaraan, barang rumah tangga, mesin, dan barang lain yang dianggap bernilai seperti surat berharga dalam segala bentuk.Pada akad rahn tidak boleh memanfaatkan marhunterlalu lama sebab akan menyebabkan marhunhilang atau rusak. ${ }^{44}$ Atas dasar inilah Pegadaian Syariah memberikan jangka waktu pinjaman selama 4 bulan atau 120 hari dan dapat diperpanjang.

Rukun yang kedua adalah marhun bih, Syafi'iyyah dan Malikiyah menetapkan syarat utama, yaitu gadaian dilakukan dengan utang yang tetap dan wajib, barang yang digadaikan dapat dinilai dengan uang sehingga dapat digunakan atau dijual untuk membayar utang, jumlah yang

\footnotetext{
${ }^{41}$ Akad Ghairu Shahih yaitu akad yang dilarang oleh Allah sesuatu yang rusak pada salah satu unsur dasar (rukun dan syarat).

${ }^{42}$ Darsono, Ali Sakti, Dkk, Dinamika Produk dan Akad Keuangan Syariah di Indonesia, Hlm.49.

${ }^{43}$ Abdul Rahman Ghazaly, Ghufron Ihsan, Sapiudin Shidiq, Fiqh Muamalat, Hlm. 267-268.

${ }^{44}$ Rachmat Syafe'i, Fiqih Muamalat, (Bandung: CV Pustaka Setia, 2001), Cet. 10, Hlm. 172
} 
diberikan untuk utang tidak lebih dari nilai asli barang, utang itu harus bersifat mengikat, seperti harga atas barang yang dipakai dalam jual beli dan terakhir, nominal utang itu diketahui secara jelas dan pasti. ${ }^{45}$ Secara praktik, marhun ditaksir sesuai dengan nilainya, pegadaian syariah memberikan jasa penaksiran atas nilai suatu barang yang dilakukan oleh rahin, jasa ini diberikan karena pegadaian syariah mempunyai alat penaksir yang akurat. ${ }^{46}$

Syarat yang harus ada dalam diri 'aqidaini(rahin dan murtahin) adalah adanya ahliyyah ${ }^{47}$ menurut jumhur ulama ahliyyah merupakan karakteristik yang dimiliki oleh orang baligh dan berakal, akad rahntidak boleh dilaksanakan oleh anak kecil yang belum baligh dan orang gila. ${ }^{48}$ Secara teori 'aqidainiharus cakap hukum dan baligh, secara praktik syarat ini telah dipenuhi karena di Pegadaian Syariah disyaratkan untuk membawa KTP atau kartu identitas resmi lainnya, dalam hal ini warga negara Indonesia bisa memiliki KTP apabila sudah berusia 17 tahun, artinya sudah cakap hukum dan baligh. ${ }^{49}$

Rukun yang terakhir adalah Shighah, ljab dan Qabul yang dilakukan oleh 'aqidainiagar bisa dilakukan serah terima kepemilikan. Yaitu adanya pernyataan yang menunjukkan kerelaan pihak yang melakukan akad. ${ }^{50}$ Secara praktik rukun ini telah dipenuhi karena kedua belah pihak menandatangani Surat Bukti Rahn (SBR) yang ada di Pegadaian Syariah, yang berisi perjanjian atas transaksi rahn tersebut.

\section{G. Masalah Riba dalam Gadai}

Perjanjian pada gadai pada dasarnya adalah akad atau transaksi utang piutang, hanya dalam gadai ada jaminannya. Setidaknya ada tiga hal dalam gadai yang memungkinkan ada unsur riba, yaitu: ${ }^{51}$

\footnotetext{
${ }^{45}$ Dimyauddin Djuwaini, Pengantar Fiqh Muamalat, Hlm. 263.

${ }^{46}$ Panji Adam, Fatwa-Fatwa Ekonomi Syariah: Konsep, Metodologi, dan Implementasinya pada Lembaga Keuangan Syariah), Hlm. 289.

${ }^{47}$ Ahliyyah adalah kecakapan dalam bertindak hukum, masing-masing dari dua pihak yang melakukan transaksi mampu melakukan transaksi kepemilikan.

${ }^{48}$ Abdul Rahman Ghazaly, Ghufron Ihsan, Sapiudin Shidiq, Fiqh Muamalat, Hlm. 266.

${ }^{49}$ Naida Nur Alfisyahri dan Dodik Siswantoro, Praktik dan Karakteristik Gadai Syariah di Indonesia, Jurnal Share, Vol. 1, No. 2, Juli-Desember 2012, Hlm. 130.

${ }^{50}$ Darsono, Ali Sakti, Dkk, Dinamika Produk dan Akad Keuangan Syariah di Indonesia, Hlm.40.

${ }^{51}$ Abdul Rahman Ghazaly, Ghufron Ihsan, Sapiudin Shidiq, Fiqh Muamalat, Hlm. 271. 
1. Apabila dalam akad gadai tersebut ditentukan bahwa arRahinatau penggadai harus memberikan tambahan kepada murtahinatau penerima gadai ketika membayar utangnya.

2. Apabila akad gadai ditentukan syarat-syarat, kemudian syarat tersebut dilaksanakan.

3. Apabila rahin tidak mampu mebayar utangnya hingga pada waktu yang telah ditentukan, kemudian murtahin menjual marhun dengan tidak memberikan kelebihan harga marhun kepada rahin. Padahal utang rahin lebih kecil nilainya daripada harga marhun.

\section{H. Kesimpulan}

Akad rahnadalah perjanjian yang menjadikan barang berharga sebagai jaminan utang hingga pihak yang bersangkutan bisa mengembalikan utang. Dengan begitu jaminan tersebut berkaitan erat dengan utang piutang. Rukun rahn adalahmarhun,marhun bih, shighah, 'aqidaini(rahin dan murtahin). Sedangkan syarat rahnadalah berakal, baligh, dan marhun ada pada saat akad dan marhun diterima oleh murtahinatau wakilnya.

Mekanisme operasional akad rahn di Pegadaian Syariah adalah masyarakat menyerahkan barang bergerak dan kemudian pegadaian menyimpan dan merawat barang tersebut di tempat yang telah disediakan oleh pegadaian. Dari proses penyimpanan, timbul biaya yang meliputi nilai dari tempat penyimpanan, perawatan dan keseluruhan proses kegiatan. Atas dasar ini, menurut pegadaian syariah dibenarkan bagi pegadaian mengenakan biaya sewa bagi nasabah sesuai jumlah yang disepakati oleh kedua belah pihak. Pegadaian Syariah akan mendapatkan keuntungan hanya dari beasewa tempat yang diambil bukan tambahan berupa bunga atau sewa modal yang diperhitungkan dari uang pinjaman. Akad rahnyang dimaksudkan adalah produk pembiayaan rahnyang ada di Pegadaian Syariah.

Dalam akad rahn di pegadaian syariah tidak disebutkan pemanfaatan marhun yang ditahan oleh pegadaian, pemanfaatan yang dilakukan dari pihak murtahin maupun dari pihak rahin yang masih dalam 
hak kepemilikan atas barang tersebut, namun pada praktiknya hal ini terjadi pada barang gadaian surat berharga, dimana rahin masih menggunakan rumah, atau kendaraan, dll. Di pegadaian hanya dijelaskan bahwa semua biaya atas marhun ditanggung oleh rahin. Dan pada penyimpanan barang hanya dijelaskan bahwa barang akan aman penyimpanannya, dan juga dalam hal barang gadaian atau marhun, pegadaian syariah sudah menentukan marhun yang akan diterima, pegadaian syariah tidak menerima marhun berupa hewan.

\section{DAFTAR PUSTAKA}

Abdul Rahman Ghazaly, Ghufron Ihsan, Sapiudin Shidiq, 2015, Fiqh Muamalat, Jakarta: Kencana Prenadamedia Group.

Abdullah bin Muhammad Ath-Thayyar, Abdullah bin Muhammad AlMuthlaq, Muhammad bin Ibrahim Al-Musa,Terj. Miftahul Khairi, 2017, Ensiklopedia Fiqih Muamalah dalam pandangan 4 Madzhab, Yogyakarta: Maktabah Al-Hanif.

Abu Amr Yusuf Ibn Abdullah Ibn Abdul Al-Bar Ibn Ashim Al-Numari AlQurthubi, 1980,Al-Kafi Fi Fiqh Ahlu Madinah Al-Maliki, Saudi Arabia: Maktabah Al-Riyadh Al-Haditsah.

Abu Muhammad Abdullah Ibn Ahmad Ibn Muhammad Ibn Qudamah AlMaqdisi, 2014,Al-Mughni wa Yalihi Al-Syarh Al-Kabir, Kairo: Dar AlHadist.

Abu Zakariya Yahya ibn Syarif Al-Nawawi, 1957,Mughni al-Muhtaj, Mesir: Musthafa al-Babi al-Halabi.

Andri Soemitra, 2016,Bank dan Lembaga Keuangan Syariah, Jakarta: Kencana.

Arif Efendi, 2013, Gadai Syariah dalam Prespektif Ekonomi Islam Studi tentang Layanan Syariah Rahn pada PT Pegadaian Persero, Jurnal Wahana Akademika, Vol. 15 No. 01, April. 
Dahlan Siamat, 2004,Manajemen Lembaga Keuangan, Jakarta: Lembaga Penerbit Fakultas Ekonomi Universitas Indonesia.

Darsono, Ali Sakti, Dkk, Dinamika Produk dan Akad Keuangan Syariah di Indonesia, (Depok: RajaGrafindo Persada, 2017), HIm.49.

Dimyauddin Djuwaini, 2015, Pengantar Fiqh Muamalat, Yogyakarta: Pustaka Pelajar.

Heri Sudarsono, 2015,Bank dan Lembaga Keuangan Syariah Deskripsi dan Ilustrasi, Yogyakarta: Penerbit Ekonisia.

Kasmir, 2008,Bank dan Lembaga Keuangan Lainnya, Jakarta: PT Rajagrafindo.

Kompilasi Hukum Ekonomi Syariah

Muhammad bin Ali Asy-Syaukani, tt,Nailul Authar, Damaskus: Daar El Fikr.

Naida Nur Alfisyahri dan Dodik Siswantoro, 2012, Praktik dan Karakteristik Gadai Syariah di Indonesia, Jurnal Share, Vol. 1, No. 2, JuliDesember.

Panji Adam, 2018,Fatwa-Fatwa Ekonomi Syariah: Konsep, Metodologi, dan Implementasinya pada Lembaga Keuangan Syariah, Jakarta: Amzah.

Rachmat Syafe'i, 2001, Fiqih Muamalat, Bandung: CV Pustaka Setia.

Rokhmat Subagiyo, 2014, Tinjauan Syariah Tentang Pegadaian Syariah (Rahn), Jurnal An-Nisbah, Vol. 1, No. 1, Oktober.

Sayyid Sabiq, 1971, Fiqh Sunnah, Beirut: Daar kitab al-Arabi.

Syaikh Sulaiman bin Ahmad bin Yahya Al-Faifi,Terj. Achmad Zaeni Dachlan, 2017, Ringkasan Fiqih Sunnah (Kitab Fiqih Sunnah Syaikh Sayyid Sabiq), Depok: Senja Media Utama, 2017

Wahbah Zuhaili, 1989,Al-figh al-Islami wa Adillatuhu, Damaskus: Daar al Fikr.

Website Pegadaiansyariah.co.id/rahn, diakses Rabu, 10 April 2018. 